\title{
Distribution of digoxin in the human heart
}

\author{
D. John COLTART* \\ M.D., M.R.C.P.
}

\author{
Margaret BillinghaM \\ M.B., B.S.
EDWARd B. Stinson
M.D.

\author{
Hans George Güllner \\ M.D.
}

\author{
ROBERT H. GOLDMAN \\ M.D.
}

\author{
SUMNER M. KaLMAN \\ M.D.
}

\section{DONALD C. HARRISON M.D.}

\author{
Divisions of Cardiology, Cardiovascular Surgery, and Department of Pharmacology, \\ Stanford University Medical Center, Stanford, California, 94305, U.S.A.
}

DATA defining the intramyocardial distribution of digoxin and its relationship to serum levels are lacking primarily owing to the limitation of an adequate supply of myocardial tissue for study. By using the recipient heart removed at the time of cardiac transplantation a supply of myocardial tissue is realized for more definitive studies of the distribution of digoxin, as reported in this study.

Although the cardiac receptors which mediate the pharmacological effect of the cardiac glycosides have neither been fully isolated nor fully identified, evidence suggests that the sodium potassium-activated adenosine triphosphatase, $\left(\mathrm{Na}^{+}, \mathrm{K}^{+}\right)$-ATPase, plays a role in the mechanism of action of the cardiac glycosides (Akera, Larsen and Brody, 1970; Besch et al., 1970). In this study, we have identified this enzyme in a microsomal fraction of the heart and measured the activity of the enzyme in vivo and to varying concentration of digoxin in vitro. Furthermore, patients undergoing transplantation in this study had end-stage cardiac disease due either to severe ischaemic heart disease or cardiomyopathy; we have, therefore, correlated the effects of cardiac histology with the distribution of digoxin in the various chambers of the heart, both on a subcellular and enzymatic level.

\section{Clinical details}

Patients considered as appropriate recipient candidates for cardiac allograft transplantation were selected for study as described by Clark et al., 1973. Six were male and one female, ages ranging between 42 and 54 years; the primary diagnosis was coronary artery disease in five patients and idiopathic cardio-

\footnotetext{
* Present address: St Thomas's Hospital, London S.E.1.
}

myopathy in two. All patients required maintenance digoxin therapy as well as large doses of diuretics before surgery. They all had been treated with digoxin for a minimum of 2 years. The last dose of the patient's usual daily maintenance glycoside therapy was given 5-7 hr before removal of the recipient heart at the time of transplantation. In patients 6 and 7 , their last dose of digoxin was given as tritiated digoxin (specific activity $150 \mu \mathrm{Ci} / \mathrm{mg}$ ) intravenously 4 and $5 \mathrm{hr}$ before surgical removal of the heart. All had normal serum electrolytes and all but one (patient 2) had normal blood urea nitrogen concentrations at the time of surgery. Patient 2 had a blood urea nitrogen level of $60 \mathrm{mg} \%$ at the time of surgery and 'toxic' plasma concentrations of digoxin before surgery. Venous blood was taken into heparin tubes after induction of anaesthesia but before intravenous infusions had been set up or cardio-pulmonary bypass initiated.

The heart was removed by the standard surgical procedure used by our group and has been discussed elsewhere (Stinson et al., 1969). The heart was quickly divided into its respective chambers, dried and immediately frozen to await pharmacological, biochemical and histological analysis.

\section{Pharmacological methods}

Tissue specimens of $1 \mathrm{~g}$ (wet weight) were cleaned from epicardium and endocardium and then minced with scissors. The tissue was transferred into a Kontes Duall glass tissue grinder (No. 23) with glass pestle and homogenized in $3 \mathrm{ml}$ of $0.04 \mathrm{~mol}$ phosphate buffer, pH 6.6. The homogenate was transferred to a separatory funnel, $15 \mathrm{ml}$ of methylene chloride were added, and the mixture shaken 
vigorously for $2 \mathrm{~min}$ by hand. This extraction step was repeated once. The clear methylene chloride phases were pooled, placed in a round bottom flask and evaporated to dryness in a Buchi Rotavapor evaporator. The residue was redissolved in $2 \mathrm{ml}$ of tris-buffered human serum albumin (BHSA). One millilitre of the BHSA solution, containing the tissue extract, was then assayed for digoxin by radioimmunoassay as described by Smith, Butler and Haber (1969). Digoxin in blood serum was assayed by the same method.

The per cent recovery from the tissues was estimated by adding known amounts of digoxin to heart tissue homogenates and determining digoxin by radioimmunoassay. Also, ${ }^{3} \mathrm{H}$-digoxin was added to homogenates and the digoxin content measured after extraction. Recoveries always exceeded $90 \%$.

Radioactivity was measured in a Nuclear-Chicago liquid scintillation counter, model Unilux.

For determination of ${ }^{3} \mathbf{H}$-digoxin in heart tissue the methylene-chloride phase containing the tissue extract was blown down in a scintillation vial with nitrogen gas, Bray's solution was added and the sample then counted. Counting efficiency was $50 \%$. Recovery, checked by external standardization, was $90 \%$.

\section{Biochemical methods}

Microsomal-bound digoxin and sodium-potassium ATPase activity was determined as previously described (Goldman et al., 1973).

\section{Histological methods}

Tissue sections were taken immediately adjacent to the muscle used for biochemical and pharmaco- logical assay. The tissue was fixed in $10 \%$ buffered formaldehyde embedded in paraffin. Sections were stained with both haematoxylin and eosin and Masson's tricome stain for fibrous tissue. The histological sections were classified into three grades: Grade 1-minimal morphological change compared to normal (donor atrium and ventricle); Grade 2-moderate-severe fibrosis but with the preservation of architecture; Grade 3-severe fibrosis-calcification with disruption or obliteration of architecture. From the sections, note was made as to whether the abnormalities were focal or the degree of involvement of the section.

\section{Results (Tables 2-8 give individual patients' results)}

The individual patient plasma concentration and total myocardial concentration of digoxin are enumerated. In some patients, the microsomal concentration in both the right and left ventricle was measured and/or sodium-potassium ATPase activity. In patients 2 and 7 an in vitro inhibition curve to $10^{-8}$ and $10^{-7}$ molar digoxin was performed. In patients 6 and 7, the last dose of digoxin was given as tritiated digoxin, either 4 or $5 \mathrm{hr}$ before transplantation and the radioactive counts in the four chambers of the heart, the total myocardial digoxin concentration and the total myocardial-tritiated concentration ratio are shown. The histology index for all seven patients is shown in Table 1 .

\section{Discussion}

Whereas a vast amount of knowledge has accrued relating to the excretion of the cardiac glycosides, little is known of the distribution of the drug within the body. The disposition of any drug is related to

TABLE 1. Histology grade

\begin{tabular}{|c|c|c|c|c|c|c|c|c|c|c|c|}
\hline \multirow{2}{*}{\multicolumn{2}{|c|}{ Patient }} & \multicolumn{2}{|c|}{ Right atrium } & \multicolumn{2}{|c|}{ Left atrium } & \multicolumn{2}{|c|}{ Right ventricle } & \multicolumn{2}{|c|}{ Left ventricle } & \multicolumn{2}{|c|}{ Septum } \\
\hline & & Grade & Comments & Grade & Comments & Grade & Comments & Grade & Comments & Grade & Comments \\
\hline 1 & J.H. & 2 & Focal & 1 & - & 1 & - & 3 & $\begin{array}{c}\text { Approx. } \\
50 \%\end{array}$ & 3 & $50 \%$ \\
\hline 2 & W.S. & 1 & - & 1 & $\begin{array}{l}\text { Sub- } \\
\text { endocardial } \\
\text { fibrosis }\end{array}$ & 1 & - & 1 & $\begin{array}{l}\text { Sub- } \\
\text { endocardial } \\
\text { fibrosis }\end{array}$ & 2 & $33 \%$ \\
\hline 3 & G.M. & 1 & - & 1 & $\begin{array}{c}\text { Sub- } \\
\text { endocardial } \\
\text { fibrosis }\end{array}$ & 1 & - & 3 & $33 \%$ & 2 & $\begin{array}{l}\text { Sub- } \\
\text { endocardial } \\
\text { fibrosis }\end{array}$ \\
\hline 4 & R.N. & 2 & - & 2 & $\begin{array}{l}\text { Sub- } \\
\text { endocardial } \\
\text { fibrosis }\end{array}$ & 1 & - & 1 & - & 2 & $33 \%$ \\
\hline 5 & G.O. & 1 & - & 2 & $\begin{array}{l}\text { Sub- } \\
\text { endocardial } \\
\text { fibrosis }\end{array}$ & 2 & - & 3 & Focal & 2 & - \\
\hline 6 & R.E. & 1 & - & 1 & - & 2 & 一 & 1 & 一 & 3 & $90 \%$ \\
\hline 7 & K.C. & 1 & - & 1 & - & 2 & $\begin{array}{l}\text { Sub- } \\
\text { endocardial } \\
\text { fibrosis }\end{array}$ & 2 & - & 2 & - \\
\hline
\end{tabular}


TABle 2. Patient 1. J.H. 52-year-old male. Coronary artery disease, antero-inferior infarction

\begin{tabular}{|c|c|c|}
\hline \multicolumn{3}{|c|}{$\begin{array}{c}\text { Plasma concentration } \\
1.8 \mathrm{ng} / \mathrm{ml} \\
\text { Myocardial concentration }\end{array}$} \\
\hline $\begin{array}{l}\text { RA } \\
\text { RV } \\
\text { LV }\end{array}$ & $\begin{array}{l}96.0 \mathrm{ng} / \mathrm{g} \\
76.8 \mathrm{ng} / \mathrm{g} \\
19.2 \mathrm{ng} / \mathrm{g}\end{array}$ & $\begin{array}{l}\text { Heart } \\
\text { Heart } \\
\text { Heart }\end{array}$ \\
\hline $\begin{array}{r}\text { Microsoma } \\
\text { RV } \\
\text { LV }\end{array}$ & $\begin{array}{r}\text { centration } \\
2.2 \mathrm{ng} / \mathrm{mg} \\
1.9 \mathrm{ng} / \mathrm{mg}\end{array}$ & $\begin{array}{l}\text { Protein } \\
\text { Protein }\end{array}$ \\
\hline $\begin{array}{r}\mathrm{Na}^{+} \mathrm{K}+\mathrm{AT} \\
\mathbf{R V} \\
\mathbf{L V}\end{array}$ & $\begin{array}{l}\text { tivity } \\
2.55 \mu \mathrm{mol} \\
2.46 \mu \mathrm{mo}\end{array}$ & $\begin{array}{l}\mathrm{mg} \text { protein } / \mathrm{hr} \\
\mathrm{mg} \text { protein } / \mathrm{hr}\end{array}$ \\
\hline
\end{tabular}

TABle 3. Patient 2. W.S. 53-year-old male. Coronary artery disease, inferior infarction

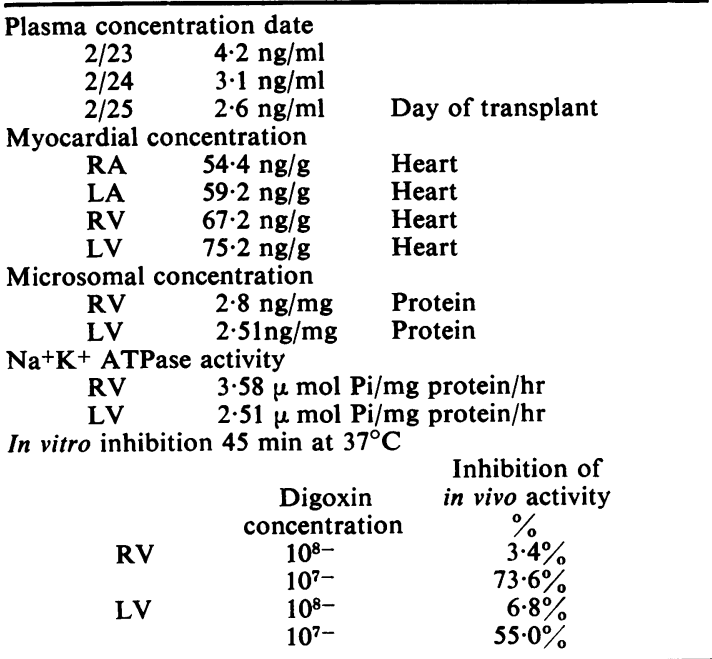

TABle 4. Patient 3. G.M. 48-year-old male. Coronary artery disease anteroseptal infarct, apical aneurysm

\begin{tabular}{lll}
\hline Plasma concentration $3.0 \mathrm{ng} / \mathrm{ml}$ & \\
Myocardial concentration & RA & $112 \mathrm{ng} / \mathrm{g}$ \\
& LA & $105 \mathrm{ng} / \mathrm{g}$ \\
& RV & $144 \mathrm{ng} / \mathrm{g}$ \\
& LV & $140 \mathrm{ng} / \mathrm{g}$ \\
\hline
\end{tabular}

TABle 5. Patient 4. R.N. 42-year-old male. Idiopathic cardiomyopathy

Plasma concentration $1.4 \mathrm{ng} / \mathrm{ml}$ Myocardial concentration RA RV $\quad 42.8 \mathrm{ng} / \mathrm{g}$ heart IVS $\quad 65.8 \mathrm{ng} / \mathrm{g}$ heart LV $\quad 76.0 \mathrm{ng} / \mathrm{g}$ heart
TABle 6. Patient 5. G.O. 47-year-old male. Coronary artery disease, anterior and interior infarction

\begin{tabular}{|c|c|}
\hline \multirow{2}{*}{\multicolumn{2}{|c|}{$\begin{array}{l}\text { Plasma concentration } 1.0 \mathrm{ng} / \mathrm{ml} \\
\text { Myocardial concentration }\end{array}$}} \\
\hline & \\
\hline & $45 \mathrm{ng} / \mathrm{g}$ \\
\hline & $45 \mathrm{ng} / \mathrm{g}$ \\
\hline & $80 \mathrm{ng} / \mathrm{g}$ \\
\hline & $120 \mathrm{ng} / \mathrm{g}$ \\
\hline \multicolumn{2}{|c|}{ Microsomal concentration } \\
\hline RV & $1.5 \mathrm{ng} / \mathrm{mg}$ protein \\
\hline LV & $1.2 \mathrm{ng} / \mathrm{mg}$ protein \\
\hline
\end{tabular}

TABle 7. Patient 6. R.E. 54-year-old male. Coronary artery disease, anteroseptal infarction. $0.25 \mathrm{mg}{ }^{3} \mathrm{H}$ digoxin i.v. $5 \mathrm{hr}$ pre-TS

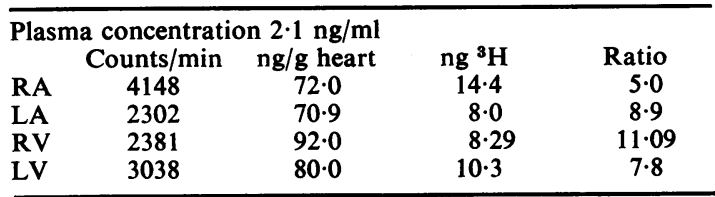

TABle 8. Patient 7. K.C. 49-year-old female. Cardiomyopathy. $0.1 \mathrm{mg}{ }^{3} \mathrm{H}$ digoxin i.v. $4 \mathrm{hr}$ pre-TS

\begin{tabular}{|c|c|c|c|c|}
\hline \\
\hline \multicolumn{3}{|c|}{$\begin{array}{c}\text { Plasma concentration } 1.5 \mathrm{ng} / \mathrm{ml} \\
\text { Counts } / \mathrm{min} \mathrm{ng} / \mathrm{g} \text { heart }\end{array}$} & \multicolumn{2}{|c|}{$\begin{array}{l}\text { Plasma concentration } 1.5 \mathrm{ng} / \mathrm{ml} \\
\text { Counts } / \mathrm{min} \mathrm{ng} / \mathrm{g} \text { heart }\end{array}$} \\
\hline \multicolumn{5}{|c|}{$\begin{array}{lll}\text { RA } & 2302 & 70.5\end{array}$} \\
\hline \multirow{3}{*}{$\begin{array}{l}\text { LA } \\
\text { RV }\end{array}$} & 1671 & $58 \cdot 0$ & $5 \cdot 8$ & $10 \cdot 0$ \\
\hline & 1825 & $57 \cdot 5$ & $6 \cdot 4$ & 9.05 \\
\hline & 2764 & $82 \cdot 0$ & $9 \cdot 6$ & $8 \cdot 5$ \\
\hline \multirow{4}{*}{ RV } & \multicolumn{4}{|l|}{ In vitro inhibition } \\
\hline & $\begin{array}{c}30 \text { min at } 37^{\circ} \mathrm{C} \\
\text { digoxin } \\
\text { concentration }\end{array}$ & \multicolumn{2}{|c|}{$\begin{array}{l}\mathrm{Na}^{+} \mathrm{K}^{+} \mathbf{A T P a s e} \\
\text { active }\end{array}$} & $\begin{array}{c}\text { Inhibition of } \\
\text { in vivo activity } \\
\%\end{array}$ \\
\hline & $10^{-8} \mathrm{~mol}$ digoxin & 5. & & $32 \%$ \\
\hline & $10^{-7} \mathrm{~mol}$ digoxin & 1 . & & $85 \%$ \\
\hline LV & $10^{-8} \mathrm{~mol}$ digoxin & 4 . & & $32 \%$ \\
\hline & $10^{-7}$ mol digoxin & 0. & & $88 \%$ \\
\hline
\end{tabular}

its distribution within and the elimination from the body. As digoxin is mainly given in clinical practice for its effect upon the heart, it is particularly pertinent to study the distribution of this drug within the diseased human heart. Human cardiac transplantation offers an opportunity to study large amounts of fresh human heart tissue. The results of this study clearly show that when the morphological architecture of the heart is altered owing to a fibrotic process secondary to old myocardial ischaemia, then the total myocardial content of digoxin is decreased. However, when on examining a purer fraction representing the possible active receptor site location of digoxin, then the disparity in drug distribution is decreased.

In patient 1 there was a fourfold difference between the total concentration in the left ventricle and right ventricle, whereas the microsomal digoxin concentrations were qualitatively similar to the plasma concentration; in patient 2 the histology was uniform 
throughout the four chambers of the heart as was the total myocardial concentration, possibly representing the relative blood supply to these four chambers; in patient 3 the plasma concentration at the time of transplant was high, higher total myocardial concentrations were also observed; in patient 4 (with idiopathic cardiomyopathy) the concentrations in the four chambers of the heart again possibly represent the blood distribution as also seen in patient 5 where the histology was focal in nature and hence did not cause any alteration in digoxin distribution. In the two patients given their last dose as labelled digoxin, the ratio of labelled to total myocardial concentration is relatively constant for all four chambers, suggesting a rapid equilibration of serum and myocardial digoxin.

The enzymatic estimations performed in this study are difficult to interpret owing to the lack of control human tissue. The only control analysis performed in this study was histology of the donor atria and ventricle. Caution has therefore to be taken in extrapolating these results, particularly in relationship to previous work of enzymatic analysis in a different species. Nevertheless, the results do have significance, since they can be compared with the relative information from control animal experiments. It is difficult to differentiate the effects of digoxin upon sodium-potassium ATPase activity from those secondary to the underlying myocardial disease process. However, in the two patients in whom in vitro inhibition to various concentrations of digoxin was performed, the enzyme could be inhibited in a dose responsive fashion. This would tend to indicate that there is still further activity of the in vivo situation. Gibson and Harris (1970) reported low values for sodium-potassium ATPase from human heart samples taken from post-mortem myocardium. These workers found that the activity of the cardiac microsomal sodium-potassium ATPase did not differ, in subjects dying from cardiac disease, from those dying from other causes. They interpreted this finding to support their previous experimental evidence that myocardial hypertrophy and prolonged administration of digitalis or diuretics had no effect on the activity of this enyme.

This present study confirms the previously reported experimental finding of an alteration in digoxin distribution in the chronically ischaemic and diseased left ventricle (Beller, Smith and Hood, 1972). It highlights the importance of an understanding of an active receptor site for the action mechanism of a drug. Previous work in relationship to plasma-total myocardial digoxin concentrations (Doherty, Perkins and Flanigan, 1967) has suggested that there is a constant relationship between these two, and hence conclusions regarding a receptor site could be extrapolated from a plasma concentration. The results of this study would tend to indicate a fallacy of such a viewpoint.

\section{Acknowledgments}

This work was supported partly by NIH Grant No. HE 5866, Program Project Grant No. 1 Pol-H1 15833-01 and the Peel Medical Research Trust. We wish to thank Miss Dorcas Sharpe for secretarial help and Miss Esther Schweizer for expert technical assistance.

Address for reprints and correspondence to Dr Coltart, St Thomas's Hospital, London S.E.1.

\section{References}

Akera, T., Larsen, F.S. \& Brody, T.M. (1970) Correlation of cardiac sodium- and potassium-activated adenosine triphosphatase activity with ouabain-induced inotropic stimulation. Journal of Pharmacology and Experimental Therapeutics, 173, 145.

Beller, G.A., Smith, T.W. \& Hood, W.B. (1972) Altered distribution of tritiated digoxin in the infarcted canine left ventricle. Circulation, 46, 572.

Besch, H.R., JR, Allen, J.C., Glick, G. \& Schwartz, A.C Correlation between the inotropic action of oubain and its effects on subcellular enzyme systems from canine 0 myocardium. Journal of Pharmacology and Experimental. Therapeutics, 171, 1.

Clark, D.A., Schroeder, J.S., Griepp, R.B., Stinson, E.B., Dong, E., Schumway, N.E. \& Harrison, D.C. (1973) Cardiac transplantation in man: review of first three years' experience. American Journal of Medicine, 54, 563.

Doherty, J.E., Perkins, W.M. \& Flanigan, W.J. (1967) The distribution and concentration of tritiated digoxin in human tissues. Annals of Internal Medicine, 66, 116.

Gibson, K. \& HARRIS, P. (1970) $\left(\mathrm{Na}^{+}, \mathrm{K}^{+}\right)$-ATPase activity in a preparation from human post-mortem myocardium. Cardiovascular Research, 4, 201.

Goldman, R.H., Coltart, D.J., Friedman, J.P., Nola, G.I., BERKE, D.K., SCHWEIZER, E. \& HARRISON, D.C. (1973) The inotropic effects of digoxin in hyperkalemia: relation to $\left(\mathrm{Na}^{+}, \mathrm{K}^{+}\right)$-ATPase inhibition in the intact animal. Circulation, 48, 830.

SMITH, T.W., Butler, V.P. \& HABER, E. (1969) Determination of therapeutic and toxic serum digoxin concentrations by radioimmunoassay. New England Journal of Medicine, 281, 1212.

Stinson, E.B., Dong, E., Jr, Iben, A.B. \& Shumway, N.E. (1969) Cardiac transplantation in man. III. Surgical aspects. American Journal of Surgery, 118, 182. 